\title{
Energy security policy of the Republic of Azerbaijan
}

УДК 327

DOI https://doi.org/10.24195/2414-

9616.2021-5.19

Tahmina Masimova

ORCID: 0000-0002-7223-3474

PhD Candidate

Baku State University

Academician Zahid Khalilov str., 23,

Baku, Azerbaijan

\begin{abstract}
Due to the limited energy resources, every country faces the problem of energy security, and therefore in the modern world, the supply of fuel and energy resources, as well as energy efficiency is one of the important indicators of the state's development and energy resources in international geopolitics. The Republic of Azerbaijan is also one of the countries with rich energy resources, developed energy infrastructure and energy system. After gaining independence, to implement this energy strategy, Azerbaijan has chosen a strategy of rapprochement with developed countries, especially with the West.

The purpose of the article is to study Azerbaijan's successful energy security policy, its role in energy security of the EU and reducing Russia's influence in the region, as well as Azerbaijan's role as a transit country.

In the course of the study, the facts were collected and summarized using methods such as scientific abstraction, logical and historical connection. The methodology of the research involves using the qualitative methods including content analysis, discourse analysis, analysis of existing rules, documents, recommendations, research papers and chronology.

The "Treaty of the Century" has given a strong impetus to the expansion of Azerbaijan's relations with the world and the strengthening of its international position. Azerbaijan also by supplying energy resources from Central Asia and the Caucasus to Western markets with BTJ oil pipeline is breaking Russia's monopoly in this area and is of strategic importance as it is the first in this context. One of the major strategic infrastructure project, the Southern Gas Corridor, is an energy security project because it strengthens Azerbaijan's position as an energy country, exports Azerbaijani gas directly to Europe and brings billions to the country. It is also an energy security project for Europe due to its diversification of energy sources and routes.

Key words: energy security, Azerbaijan, Treaty of the Century, Baku-Tbilisi-Jeyhan oil pipeline, Southern Gas Corridor.
\end{abstract}

Introduction. In the geopolitical literature, energy security is considered as an important component of national security. Energy security is a type of link between the availability of natural resources for energy consumption and national security. Energy security plays a crucial role as one of the structural elements of national security. In the context of modern political realities, a number of political experts characterize the state's energy resources as a leading factor in world politics.

The Republic of Azerbaijan is also one of the countries with rich energy resources, developed fuel and energy infrastructure and energy system.

After gaining independence, to implement the energy security strategy, Azerbaijan has chosen a strategy of rapprochement with developed countries, especially with the West.

Purpose and objectives. Studying Azerbaijan's successful energy security policy, its role in energy security of the EU and reducing Russia's influence in the region are purposes of the article. The object of research is the energy policy of the Republic of Azerbaijan in modern international relations, the main directions of energy security policy and the role of Azerbaijan in the energy security of the European Union.

Research methods. In the course of the research, the facts were collected and summarized using methods such as scientific abstraction, logical and historical connection.
The scientific novelty. The study analyzes aspects of the energy security policy of the Republic of Azerbaijan, the process of modernization of the energy industry of Azerbaijan after independence and the oil diplomacy of Azerbaijan. The study has collected a large amount of factual and statistical data on the issues raised in recent years.

Results of the research. The foundations of Azerbaijan's energy security policy date back to the 1994 Treaty of the Century. After the signing of the Contract of the Century in 1994, the question of how to supply oil to world markets came up. Therefore, discussions on new pipelines began in the early years of the agreement. The most discussed pipeline was Baku-Tbilisi-Jeyhan. After that, the plan to transport Azerbaijani oil from Ceyhan to the Mediterranean and from there to world markets came to the fore. The agreement was finally signed as a result of intense discussions on the BTC Crude Oil Pipeline Project, which took place 10 years after Azerbaijan gained independence in 1991.

Baku-Tbilisi-Erzurum project is designed to deliver natural gas from the Shah Deniz field via Georgia to the Turkish-Georgian border.

The "Joint Declaration on the Southern Gas Corridor" signed with the European Commission in 2011 marked the beginning of a completely new phase in cooperation of Azerbaijan with Europe. Segments of the Southern Gas Corridor include the Shah Deniz2, the South Caucasus Pipeline Expansion, the Trans- 
Anatolian Pipeline (TANAP) and the Trans-Adriatic Pipeline (TAP). The Southern Gas Corridor system is designed to increase the capacity of each of its segments, including TAP, to supply possible additional volumes of gas in the future. SGC is a major strategic infrastructure project. This project will not only serve Azerbaijan in the future, but also the support of Western countries for the project.

The International Energy Agency (IEA) defines energy security as "the uninterrupted availability of energy sources at affordable prices" [15].

Based on the final document adopted at the G-8 summit in St. Petersburg in 2006, it can be explained that global energy security means providing all the world's resource-consuming and producing countries with sustainable energy resources, availability of energy resources at affordable prices, minimal damage to the environment during the extraction of resources, as well as the creation of sustainable socio-economic development for the world community $[7$, p. 30].

Energy security plays a crucial role as one of the structural elements of national security. In the context of modern political realities, a number of political experts characterize the state's energy resources as a leading factor in world politics.

The Republic of Azerbaijan is also one of the countries with rich energy resources, developed fuel and energy infrastructure and energy system.

The foundations of Azerbaijan's energy security policy date back to the 1994 Treaty of the Century.

The 7,4 billion agreement involved 11 international oil companies (Amoco, BP, McDermott, UNOCAL, SOCAR, Lukoil, Statoil, TPAO, Pennzoil, Ramco, Delta) representing 7 countries (Azerbaijan, USA, Great Britain, Russia, Turkey, Norway and Saudi Arabia) as contractor parties.

The "Treaty of the Century" has given a strong impetus to the expansion of Azerbaijan's relations with the world and the strengthening of its international position, created favorable conditions and a favorable basis for integration into the European Union, the establishment and development of friendly and strategic relations with major countries.

After the "Contract of the Century", 26 new oil contracts were signed with 36 leading companies from 16 countries. Under these agreements, up to $\$ 70$ billion in foreign investment was planned to be invested in Azerbaijan's oil industry for 30 years.

As a result of these investments, oil production in Azerbaijan has grown significantly and reached its maximum level in 2008 - 45.5 million tons. As of the end of 2008, the budget of the State Oil Fund of Azerbaijan was \$ 11.4 billion, of which $\$ 6$ billion was transferred to the state budget [4, p. 43].

On September 14, 2017, the "Contract of the Century" was signed, which provides for the extension of the "Contract of the Century" until 2050 and the allo- cation of new shares. Under the new agreement, BP will be the operator of oil production in Azerbaijan for another 32 years. According to the new distribution, BP's share was reduced to $30.4 \%$, while SOCAR's share was increased to $25 \%$.

Azerbaijan's proven oil reserves are 7 billion barrels (1 billion tons), which is $0.6 \%$ of world oil reserves. Oil experts estimate the country's proven oil reserves at 13 billion barrels. The Azerbaijani government puts this figure at 17.7 billion barrels. Azerbaijan's proven natural gas reserves are 1.31 trillion cubic meters, or $0.7 \%$ of the world's natural gas reserves [12, p. 74].

After the signing of the Contract of the Century in 1994, the question of how to supply oil to world markets came up. In fact, there was an oil pipeline from Baku to Novorossiysk. (The Baku-Novorossiysk oil pipeline was repaired and commissioned on 12 November 1997.) However, the line was not of interest to the EU, as energy was transported to Europe via Russia and generally did not serve the purposes of the project members. Moreover, there was not enough power to transport oil to Baku-Novorossiysk. Therefore, discussions on new pipelines began in the early years of the agreement. The three most discussed lines at the time were:

- Oil pipeline from Baku to Supsa, Georgia (BakuSupsa);

- A pipeline to transport oil to the Turkish port of Ceyhan (BTC) via Tbilisi, Georgia;

- Oil transportation line through Iran (South line).

Among them, the most valued was the BTC line [9, p. 141]. Although the third line was off the agenda, over time the Baku-Supsa and BTC pipelines became a reality. Although Russia has insisted on delivering Azerbaijani oil to the West via Russia, Azerbaijan has been able to build new pipelines with US support. Russia was disappointed when an international consortium formed after the Treaty of the Century announced in October 1995 that it would transport "early oil" from Azerbaijan (initially) via both the BakuNovorossiysk and Baku-Supsa pipelines. Thus, Russia's only hand in the transportation of Azerbaijani oil was broken. US President Bill Clinton was particularly influential in the AIOC's (Azerbaijan International Oil Company) Baku-Supsa route, calling Azerbaijani President Heydar Aliyev and offering a route for "early oil" via Georgia. The first information about this line was included in the report of the US company in April 1995 [11, pp. 354-355] Baku-Supsa, also known as the Western Export Pipeline, transports Azerbaijani oil to world markets via Georgia. Crude oil is loaded onto tankers at Georgia's Supsa terminal and shipped to Europe via the Istanbul Strait.

On March 8, 1996, the Presidents of Azerbaijan and Georgia Heydar Aliyev and Eduard Shevardnadze signed an agreement on the construction of the Baku-Supsa line, which was built in 19971998. "Early oil" began to be exported on this line on 
April 17, 1999. The biggest advantage of this line is that it does not mix with Russian oil and carries only better and cleaner Azeri Light [16]. On 12 August 2008, in connection with the Russian-Georgian war and the South Ossetian conflict, BP briefly suspended the Baku-Supsa line for security reasons [14].

Although the Baku-Supsa pipeline, originally referred to as the Western Line from Georgia, and the Baku-Novorossiysk oil pipeline, referred to as the Northern Line in Russia, were requested to transport Baku oil to Europe, an alternative pipeline was on the agenda. Among the reasons for the new project were the decline in market value due to the mixing of higher quality Azerbaijani oil Azeri Light with lower quality Russian oil Ural, and the threat of overloading the Istanbul and Canakkale straits. It can be shown that the West, especially the United States, wants a pipeline that does not depend on Russia [6, pp. 118-120]

Russia was then unable to transport "essential oil" and in 1999 the BTC project was approved and began construction. In 1998, the US government identified the BTC project as the best way to bring Azerbaijani oil to the international market. Although AIOC is concerned that the BTC is more expensive, the BTC Agreement was signed in 1999 during the OSCE Summit as a result of Washington's insistence and persuasion [11, pp. 355-356].

After that, the plan to transport Azerbaijani oil from Ceyhan to the Mediterranean and from there to world markets came to the fore. The agreement was finally signed as a result of intense discussions on the BTC Crude Oil Pipeline Project, which took place 10 years after Azerbaijan gained independence in 1991. The reason for the protracted process was the "economic" side of the project and the "political" side of the US, not the "tactical wars" with Russia. The project envisages the construction of a pipeline with a capacity of 1 million tons of oil per day, which will transport oil from the Azerbaijani sector of the Caspian Sea to the Turkish port of Ceyhan via Tbilisi. The official opening of the line took place in July 2006 at the Ceyhan terminal. By supplying energy resources from Central Asia and the Caucasus to Western markets, BTC is breaking Russia's monopoly in this area and is of strategic importance as it is the first in this context. The project also freed Georgia from Russia's influence, connected it to world markets through Turkey, and brought it to EU countries that are particularly sensitive to energy security [5, pp. 89-91].

On May 25, 2005, the tested oil flow through the BTC pipeline was carried out, and in June 2006, normal oil flow began [2, pp. 103-106].

BTC's oil production is 1.2 million barrels per day. From June 2006 to the end of 2017, more than 383 million tons (approximately 2.87 billion barrels) of oil was transported via the BTC pipeline to the Turkish port of Ceyhan and shipped to world markets after being loaded on 3,758 tankers. In 2017, 34 million tons (256 million barrels) of oil were exported via the BTC and loaded on 333 tankers in Ceyhan. On September 14, 2017, the "Contract of the Century", which will transport Azerbaijani oil to the world, was renewed and the contract was extended until 2049. Under the new agreement, SOCAR's interest rate was raised from $11.6 \%$ to $25 \%$ [17].

Since 2008, Kazakhstan's Tengiz oil has been transported in small quantities via the BTC. Although this transport was stopped for some reason between 2010 and 2013, in 2013 oil was resumed. Kazakhstan annually transports 5 million tons of oil to European markets via the BTC. In addition, Turkmenistan produces 11.8 million tons of oil a year, a small part of which is transported to the world market via BTC [8, p. 73].

It is known that Turkmenistan transported 3.3 million tons of oil through BTC in 2013 and 5.6 million tons in 2014 [12].

After Azerbaijan gained independence in 1991, many negotiations began in 1992 for the joint development of the Shah Deniz natural gas field with international companies, and the first contract was signed on June 4, 1996 in Baku. The agreement provides for the allocation of shares for research, development and production in the Shah Deniz natural gas field. Statoil (Norway), BP (UK), SOCAR, Lukacip (Russia-Italy), Nico (Iran), Total (France), TPAO (Turkey) [1, p. 75].

Baku-Tbilisi-Erzurum (BTE) natural gas after the discovery of a large gas field with a total area of $860 \mathrm{~km} 2$, located $70 \mathrm{~km}$ southwest of Baku and the lack of the necessary pipeline to deliver natural gas to international markets in the most profitable way pipeline project came to the fore. The BTE project, also known as the South Caucasus Pipeline, is designed to deliver natural gas from the Shah Deniz field from Georgia to the Turkish-Georgian border. The Georgian part of the project, the construction of which began in 2004, was completed in 2006 and started immediately [3, p. 164].

When the first gas contract for the Shah Deniz field was signed in 1996, gas contracts were not considered as profitable because the issue of energy security was not as relevant as it is now. However, Azerbaijan, which took the first step with the BakuTbilisi-Erzurum gas pipeline, laid the foundation for our country's desire to be recognized as a major gas exporter in the future with this project. Although there are various opportunities to sell Azerbaijan's natural gas reserves, official Baku has preferred to build an export pipeline to Europe. The "Joint Declaration on the Southern Gas Corridor" signed with the European Commission in 2011 marked the beginning of a completely new phase in cooperation. Currently, seven countries - Azerbaijan, Georgia, Turkey, Bulgaria, Greece, Albania, Italy - are involved 
in the implementation of the Southern Gas Corridor (SGC), and three Balkan countries - Bosnia and Herzegovina, Croatia and Montenegro - are expected to join the project in the next phase. . In the future, new branches of the SGC are expected to be established, which will allow exporting Azerbaijani gas to more European countries.

Segments of the Southern Gas Corridor include the Shah Deniz-2, the South Caucasus Pipeline Expansion, the Trans-Anatolian Pipeline (TANAP) and the Trans-Adriatic Pipeline (TAP).

In 2011, the EU and Azerbaijan signed a Joint Statement in support of the creation of routes to transport gas directly from the Caspian Sea to Europe. This was a key issue for the Southern Gas Corridor project. The Joint Statement, together with the Intergovernmental Agreements on TANAP and TAP, laid the groundwork for long-term gas sales agreements. Then, in 2012, as a result of the activities of the political leadership of Turkey and Azerbaijan, an agreement was reached on the construction of the TAP pipeline. On June 27, 2012, Azerbaijan and Turkey signed an agreement on TANAP. Finally, on September 20, 2014, the foundation of the Southern Gas Corridor was laid [16].

The 1,850-kilometer TANAP, which runs from the Georgian-Turkish border to the Turkish-Greek border, is a very important project as a regional energy provider, especially in Europe. It is no coincidence that in 2020, TANAP was awarded the Project of the Year Award by the Project Management Institute (PMI), the world's leading association for project, program and portfolio management [19].

The Trans-Adriatic Pipeline (TAP) was laid on May 17, 2016 in Thessaloniki, Greece. The construction of the 878-kilometer pipeline, which runs from the Turkish-Greek border to Greece, Albania and the bottom of the Adriatic Sea to southern Italy, has been completed. This project creates great opportunities for the delivery of Azerbaijani gas to major European markets such as Italy, Germany, France, Great Britain, Switzerland and Austria. TAP is strategically important for access to new supply sources. TAP transports natural gas to Europe from the giant Shah Deniz field in the Azerbaijani sector of the Caspian Sea. TAP can stimulate gas supplies to Southeast European countries through interconnectors to be built in the future. As the last segment of the Southern Gas Corridor, TAP, which provides Europe with reliable access to new natural gas sources and is of strategic importance, plays an important role in strengthening Europe's energy security, diversifying supplies, and serving decarbonization goals.

The goal of the energy strategy is to form a very strong, large-scale gas corridor. Given that the Azerbaijani sector of the Caspian Sea is rich in gas and condensate resources, the Southern Gas Corridor system is designed to increase the capacity of each of its segments, including TAP, to supply possible additional volumes of gas in the future. In the future, Turkmenistan and Kazakhstan may use the existing infrastructure to export their large gas resources to the European market. It is also possible to add gas and energy resources of Iran and Iraq. This is a unique project designed to benefit all countries on the road from the Caspian Sea to the heart of Europe.

On December 31, 2020, the Trans-Adriatic Gas Pipeline (TAP), the last segment of the Southern Gas Corridor, began transporting commercial gas from Azerbaijan. For the first time in history, Azerbaijan has managed to export its natural gas to the European market through pipelines. After TAP was successfully connected to the Italian gas distribution network on November 15, 2020, on December 31, commercial natural gas was delivered from Melendugno to Italy via SNAM Rete Gas (SRG) and from Nea Mesimvria to Greece and Bulgaria via DESFA. [8] The pipeline will meet $20 \%$ of Greece's, $30 \%$ Bulgaria's and $10 \%$ Italy's natural gas needs.

SGC is a major strategic infrastructure project. This project will not only serve Azerbaijan in the future, but also the support of Western countries for the project. However, the existing gas resources of Azerbaijan as a whole consist not only of Shah Deniz-2, but also of Absheron, Umid, Karabakh, Babek and other fields, which currently have proven gas reserves of 2.6 trillion cubic meters. The Shah Deniz field, the largest natural gas source discovered in Azerbaijan, is the main resource base of the SGC. The initial geological gas reserves of this huge field are 1.2 trillion cubic meters.

The Southern Gas Corridor is part of the EU's energy policy. The use and import of natural gas in the EU member states has increased over the years. In Europe, natural gas production has declined and dependence on imports has increased. This process has made Europe more dependent on Russia, which uses its natural resources for political purposes, because Russia is Europe's main gas supplier. The Southern Gas Corridor is a project launched by the European Commission to encourage the diversification of routes and gas supplies to Europe in order to reduce the EU's dependence on Russia. Due to Washington's interests in the region, the Southern Gas Corridor is of geopolitical importance not only for the EU but also for the United States. This was the main reason why the United States actively supported the EU's efforts.

For the first time, SGC is changing the energy map of the entire region by exporting Caspian gas resources directly to European markets. On the other hand, natural gas will be the most produced fuel by 2040, growing by 1.5-1.8\% per year. Over the same period, global natural gas exports will increase by $50 \%$, and experts predict that the European market will attract most of this growth, which will once again increase the importance of SGC infrastructure. The conclusion of a 15-year agreement with the importing 
countries on the volume of gas to be exported under the SGC is, of course, one of the main factors that make the project superior to other alternatives. At present, our revenues from both stages of the Shah Deniz field are projected to exceed $\$ 100$ billion, but it is not ruled out that revenues may be higher, and in the medium and long term, Azerbaijan itself can act as a transit country for gas exports to European countries.

The article, "Why does the West need Azerbaijan?", published by the famous American publication "Foreign Policy" on the importance of the project, authored by Luke Coffey and Afghan Oil, answers these questions, emphasizing that Azerbaijan plays an important role in energy supply, trade and digital communications between East and West [18].

In July 2021, the governments of Azerbaijan and Turkmenistan reached an agreement on cooperation in the Dostlug (Friendship) oil and gas field. With the joint development of the Dostlug offshore oil and gas field by Turkmenistan and Azerbaijan, the Trans-Caspian submarine pipeline will be able to export gas to European countries. In this case, the pipeline can connect to the Southern Gas Corridor, which connects Azerbaijan with the EU through Georgia and Turkey [13].

Due to the fact that not every country has access to energy sources, the high cost of access and transit, the gradual depletion of resources and the damage to the environment, there is a need for new sources of energy production. It is expected that the world's population will need $45 \%$ more energy in 2030 than it consumes today, raising concerns that new energy production could meet growing demand. [10, pp. 1-2] Against this background, the type of renewable energy comes to the fore as an alternative to non-renewable energy in energy production.

Azerbaijan is one of the countries with high potential for renewable energy sources. Thus, the potential of economically viable and technically usable renewable energy sources of the country is $26,940 \mathrm{MW}$, including 3,000 MW for wind energy, 23,040 MW for solar energy, $380 \mathrm{MW}$ for bioenergy potential, and $520 \mathrm{MW}$ for mountain rivers.

One of the main steps taken in order to effectively use the renewable energy potential in our country was the adoption in 2004 of the "State Program on the use of alternative and renewable energy sources in the Republic of Azerbaijan". The adoption of the program has created ample opportunities for radical changes in the use of renewable energy sources and the assessment of our country's potential in this area. The main goal is to increase the share of renewable energy sources in electricity generation capacity to $30 \%$ by 2030 . In order to achieve this goal, along with public investment, measures are being taken to use new production facilities through private and foreign investment.
About $90 \%$ of foreign investment in Azerbaijan is in the energy sector. By 2024, the country's oil and natural gas revenues are expected to reach $\$ 200$ billion.

Conclusions. The oil factor plays an important role in solving the problems of political and economic development of Azerbaijan in terms of both political and international projects. In this context, the development of the oil sector and cooperation with foreign companies in the post-independence period has made a great economic contribution to Azerbaijan. First of all, the country has been equipped with modern technologies, the assets of the oil industry have been renewed, institutions and organizations have been developed to assist in the development of this sector, and the infrastructure of the oil and gas industry has been modernized. In addition to all this, the amount of taxes paid by foreign companies to the state budget has increased, thousands of new enterprises have been opened, and as a result, all this has led to an increase in the economic potential. Oil profits ensured the country's independent economic and investment policy, and the living standards of the country's population began to improve.

As a result of Azerbaijan's successful energy security policy, a number of political and economic problems of the country have been resolved. Thanks to this policy, Azerbaijan, which gained its independence in the conditions of conflict, began to cooperate with the world's leading states and companies. Hundreds of thousands of jobs have been created with revenues from energy projects, unemployment has been reduced to 5\% and the living standards of the country's population have been raised. Azerbaijan's energy security policy has also played an important role in resolving the Nagorno-Karabakh conflict, which is a priority of Azerbaijan's foreign policy. It is the result of a successful energy security policy that today no project of international importance in the South Caucasus can't be realized without the participation of Azerbaijan. Azerbaijan's role as an exporter and transit country in a major project such as the Southern Gas Corridor is one of the country's greatest achievements in energy security policy.

\section{REFERENCES:}

1. Aslan Y. Hazar Petrolleri Kafkas Korduğumu ve Turkiye [Caspian Oil Caucasus Knot and Turkey], Personal Edition, Ankara, 1997, 232 p.

2. Babayeva V. Haydar Aliyev Donemi TurkiyeAzerbaycan ilishkileri [Turkey-Azerbaijan Relations in Heydar Aliyev Era], Istanbul Commerce University, Institute of Social Sciences İstanbul, 2013.

3. Bahadır O.D., Ozdal H., Necefoglu H. Yeni Donemde Turk Dısh Politikası Uluslararası IV. Turk Dısh Politikası Sempozyumu Tebligleri [Turkish Foreign Policy in the New Era International IV. Turkish Foreign Policy Symposium Papers], USAK Publications, Ankara, 2010, $490 \mathrm{p}$. 
4. Ciaretta A., Nasirov S. Impact of Azerbaijan`s Energy Policy on the Development of the Oil Sector, Fourth Quarter, 2010.

5. Cal S. Baku-Tiflis-Ceyhan Boru Hattı Projesi Kapsamındaki Anlaşmaların Hukuki Yönden Değerlendirilmesi [Legal Evaluation of Agreements Within the Scope of Baku-Tbilisi-Ceyhan Pipeline Project], Ankara University Journal of SBF, v. 63, 2008, p. 4.

6. Ener M., Ahmedov O. Turkiye-Azerbaycan Petrol-Dogalgaz Boru Hattı Projelerinin Ulke Ekonomileri ve Avrupa Birligi Achısından Onemi [Importance of TurkeyAzerbaijan Oil-Natural Gas Pipeline Projects for Country Economies and European Union], Turkey's Economic Transformation Process: In Memory of Izmir Economy Congress II. National Economics Congress, Dokuz Eylul University Press, İzmir, 2010.

7. Erjov Y.A. Globalnaya energeticheskaya bezopasnost i interesi Rossii [Global energy security and interests of Russia], monographic research, Moscow, 2009, 229 p.

8. Garibov A. The Trans-Caspian Corridor: Geopolitics of Transportation in Central Eurasia, Caucasus International, n. 1, 2016.

9. Kahraman A. Hazar Ekseninde Boru Hatları Diplomasisi, Stratejik Arashtırmalar Dergisi, Stratejik Ongoru [Pipeline Diplomacy on the Caspian Axis], Journal of Strategic Studies, Strategic Foresight, n. 12, 2008.

10. Luft G., Korin A. Energy Security: In the Eyes of the Beholder, Energy Security Challenges for the 21st Century: A Reference Handbook, Santa Barbara Praeger Security International, California, 2009, 341 p.
11. Yapıcı M.I. Rus Dısh Politikasını Olushturan İch etkenler: Yeltsin ve Putin Donemleri [Internal Factors Forming Russian Foreign Policy: Yeltsin and Putin Periods], First Edition, USAK Publications, Ankara, 2010, 564 p.

12. Azerbaijani gets $3 \%$ rise in oil transportation via BTC, URL: http://en.apa.az/azerbaijan_energy_and industry/turkmenistan-to-resume-oil-transportationvia-btckazakhstan-holding-negotiations.html (20.10.2021)

13. Azerbaijan, Turkmenistan Agree to Deepen Cooperation on Dostlug Offshore Field. URL: https://caspiannews.com/news-detail/azerbaijan-turkmenistan-agree-to-deepen-cooperation-on-dostlug-offshore-field-2021-7-30-0/ (25.10.2021)

14. Baku Supsa Oil Pipeline. URL: https://www.sourcewatch.org/index.php/Baku_Supsa_ Oil_Pipeline (25.10.2021)

15. Energy security. URL: https://www.iea.org/topics/ energy-security (25.10.2021)

16. Southern Gas Corridor. URL: https://minenergy.gov.az/az/layiheler/cenub-qaz-dehlizi_2196 (25.10.2021)

17. The official cite of BP. URL: https://www.bp.com/ az az/caspian/operationsprojects/pipelines/BTC1.html (25.10.2021)

18. Why the West Needs Azerbaijan. URL: https://foreignpolicy.com/2018/05/28/why-the-westneeds-azerbaijan/ (25.10.2021)

19. 2020 PMI® Project of the Year Winner. URL: https://www.pmi.org/learning/library/2020-project-yearturkey-pipeline-12567 (25.10.2021)

\section{Політика безпеки енергетики Республіки Азербайджан}

Тахміна Масімова

ORCID: 0000-0002-7223-3474

докторант

Бакинського державного університету вул. Академіка Захида Халілова, 23, Баку, Азербайджан
Через обмеженість енергетичних ресурсів кожна країна стикається з проблемою енергетичної безпеки, а тому в сучасному світі постачання паливно-енергетичних ресурсів, а також енергоефективність є одним із важливих показників розвиток держави та енергетичні ресурси в міжнародній геополітиці. Республіка Азербайджан також $\epsilon$ однією з країн із багатими енергетичними ресурсами, розвиненою енергетичною інфраструктурою та енергетичною системою. Отримавши незалежність, для реалізації цієї енергетичної стратегії Азербайджан вибрав стратегію зближення з розвиненими країнами, особливо із Заходом.

Метою статmі є дослідження успішної політики енергетичної безпеки Азербайджану, його ролі в енергетичній безпеці ЄС та зменшення впливу Росії в регіоні, а також ролі Азербайджану як транзитної країни.

У процесі дослідження фракти були зібрані та узагальнені за допомогою таких методів, як наукова абстракція, логічний та історичний зв'язок. Методологія дослідження передбачає використання якісних методів, включаючи контент-аналіз, аналіз дискурсу, аналіз правил, документів, рекомендацій, наукових робіт та хронології. «Договір століття» дав потужний імпульс розширенню відносин Азербайджану зі світом та зміцненню його міжнародних позицій. Азербайджан також иляхом постачання енергоресурсів із Центральної Азії та Кавказу на західні ринки нафртопроводом ВTJ порушує монополію Росії в цій сфрері $і$ має стратегічне значення, оскільки є першим у иьому контексті. Один із найбільших стратегічних інфрраструктурних проєктів - Південний газовий коридор - че проєкт енергетичної безпеки, оскільки він зміцнює позиції Азербайджану як енергетичної країни, експортує азербайджанський газ безпосередньо до Європи та приносить країні мільярди. Це також проєкт енергетичної безпеки для Європи через диверсифікацію джерел енергії та марширутів.

Ключові слова: енергетична безпека, Азербайджан, «Договір століття», нафртопровід Баку-Тбілісі-Джейхан, Півде 